\title{
INVESTIGATION FUTURE PLANNING OF RAILWAY NETWORKS IN THE ARABS GULF COUNTRIES
}

\author{
MOHAMMAD EMAD MOTIEYAN NAJAR \& ALIA KHALFAN AL RAHBI \\ Department of Civil Engineering, Middle East College, Muscat, Oman
}

\begin{abstract}
Trans-border railroad in the Arabian Peninsula dates back to the early 20th century in Saudi Arabia. Over the recent decades due to increasing population and developing industrial zones, the demands are growing up over time. The Gulf Cooperation Council (GCC) is now embarking on one of the largest modern cross-border rail networks in the world. This is an ambitious step regarding the planning and establishment of the rail network connecting all the six GCC countries. This railway network will go through at least one city in each country to link the cities of Kuwait in Kuwait, Dammam in Saudi Arabia, Manama in Bahrain, Doha in Qatar, the cities of Abu Dhabi and Al Ain in the United Arab Emirates and Sohar and then Muscat in Oman in terms of cargo and passengers. The area of investigation covers different aspects of the shared Arabian countries rail routes called 'GCC line' and their national rail network. The aim of this article is to study the existing future plans and policies of the GCC countries shared line and domestic railway network. This article studies the national urban (light rail transportation (LRT), metro (subways) and intercity rail transportation to appraise the potential of passenger movement and commodity transportation at present and in the future. The tabular informative technical aspects of operation, such as traffic load yearly, speed, cost of the project, tracks length and track types, are supplied. Result of the analysis gives an overview of the Gulf Arabian countries railway plan and project properties to generate opportunities for international companies and researchers. It shows that there is a big boom and development for the upcoming railway transportation in the GCC countries.

Keywords: Gulf Cooperation Council (GCC), Operation, planning and policy, Railway network, Railway track, urban and intercity transportation.
\end{abstract}

\section{INTRODUCTION}

Railways are one of the transportation modes of increasing relevance to the growth of developing countries and influencing civilizations. On the other hand, the rail system is costly and takes years to build and develop. Nevertheless, in comparison with other modes, railways are saving energy and environmentally friendly [1]. The Arabian Peninsula is an important part of the continent of Asia. It is the largest contingent in the semi-West Asia, which covers the Gulf Cooperation Council (GCC) countries [2]. The GCC is a regional intergovernmental political and economic union consisting of all the Arab states of the Persian Gulf with the exception of Iraq. The GCC countries in 1981 have been intended as one country by all of the residents in the area - a means of cooperation and brotherly relations, which were and are still sustained in the Gulf area. The GCC countries are Oman, the Kingdom of Saudi Arabia (the KSA), Qatar, Bahrain, Kuwait and the United Arab Emirates (the UAE), which are developing countries. These countries need to diversify away from oil or gas to develop exploitation of industrialization and mineral wealth. There is a proposal to build railway links together. Based on the proposal this railway route starts from Kuwait to Oman via the UAE and the KSA via causeways through Qatar and Bahrain [3].

Rail is $30 \%$ cheaper compared to other transports and uses 50\%-80\% less energy and $70 \%$ less carbon dioxide emissions. In addition, it is safer than other transports and produces less noise pollution. For these reasons, the mass-transit sector is rapidly becoming one of the biggest investment destinations in the Arabian Gulf region as governments began recently to pay their attention towards developing this previously neglected area. Subsidized fuel and 
low vehicle tax have made the Gulf residents heavily dependent on motoring. Moreover, with Gulf countries witnessing annual population growth of 5\%-8\%, urban areas are facing an increasing congestion [2]. This is forcing governments to invest on improving the public transport infrastructure. Almost every member country of the GCC has announced plans for massive spending on this sector, with rail projects. The GCC region is projected to invest more than US\$100 billion over the next decade in rail projects [1].

Railways in the GCC are used for transporting people and freight. In the GCC countries, the domestic trips are different due to the countries' geography [1]. The main objective of this article is to study the rail network in Oman, Saudi Arabia (the KSA), Qatar, Bahrain, Kuwait and the UAE and analyse all properties that relate to the railway track and key issues in operation. The aim of this article is to investigate the existing and future plans and policies of the GCC countries shared line and domestic railway network.

\section{THE GULF COOPERATION COUNCIL RAILWAY NETWORK}

The main route for the GCC railways starts from Kuwait city to Muscat city in Oman and ends there. Railway route continues and passes through main cities and has some loops in Bahrain, Qatar and Emirate as shown in Fig. 1. Moreover, this GCC has to cross over the bridge between Qatar and Bahrain and then through another causeway to Dammam in the KSA. The length of this bridge is $40 \mathrm{~km}$ and the bridge is only used for railways [4]. The total length of the main railway route is around 2,177 km [5]. The transport by train after the implementation of the Gulf railway network is expected to transfer an estimated 31 million tons of goods by train in 2017, which will be 17 million tons of heavy raw materials, 4.1 million tons of imported goods by some of the GCC countries from outside and the rest is passenger traffic [1]. The total cost of the GCC railway network is estimated to be $\$ 25$ billion apart from the inner project of each country. In Table 1, the station and route types are depicted. The GCC route might later on extend up to Jordan and after that to the European Union.

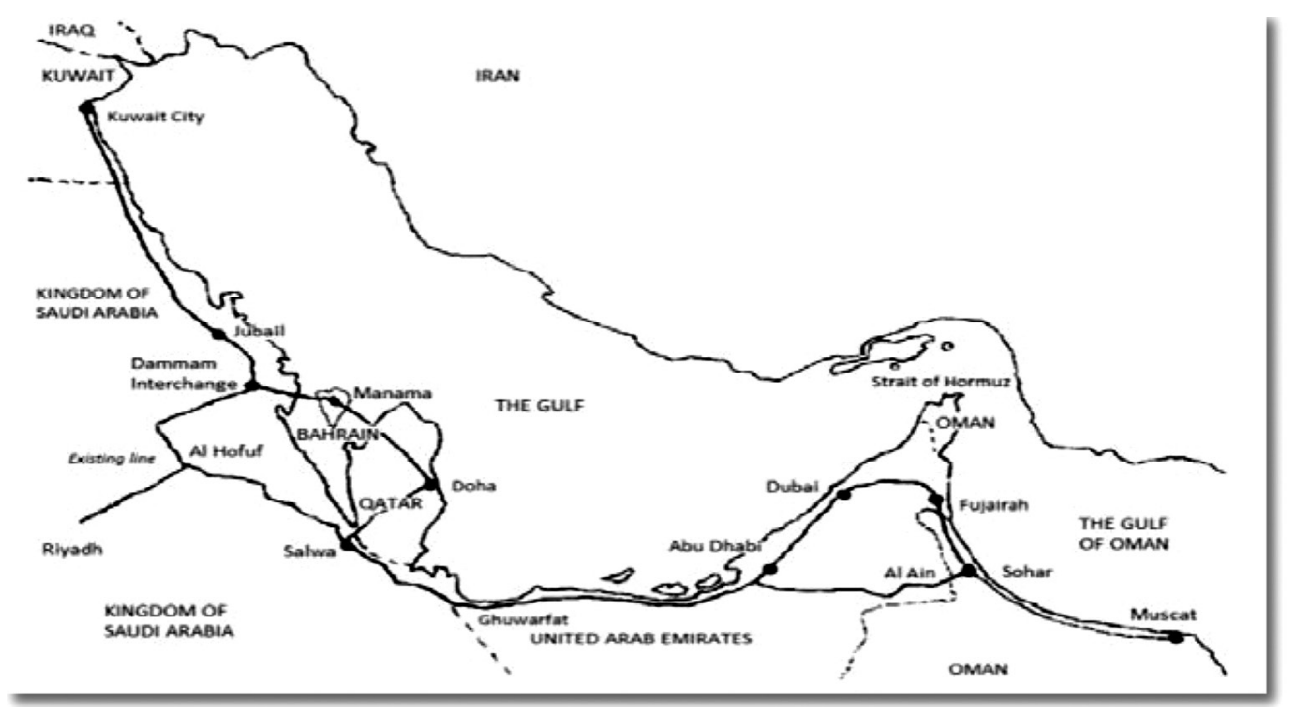

Figure 1: The Gulf Cooperation Council railways network [6]. 
Table 1: Details of the GCC countries railways network.

\begin{tabular}{llllc}
\hline Stations & Lines & Station types & Member states & Route $(\mathrm{km})$ \\
\hline Kuwait city & Main line & Large & Kuwait & 145 \\
Jubail & Main line & Small & KSA & \\
Dammam interchange & Main line & Large & KSA & 663 \\
Salwa & Main line & Small & KSA & \\
Manama & Branch or loop line & Large & Bahrain & 36 \\
Doha & Branch or loop line & Large & Qatar & 283 \\
Abu Dhabi & Loop line & Large & UAE & \\
Dubai & Loop line & Large & UAE & 684 \\
Fujairah & Loop line & Small & UAE & \\
Sohar & Main line & Small & Oman & 306 \\
Muscat & Main line & Large & Oman & \\
\hline
\end{tabular}

There are other factors like the speed of the locomotives, loading gauge and the type of locomotives where the issues can arise. These all require political decision-making.

In Oman and the UAE there will be issues regarding the loading gauge due to the presence of high mountains; thus, this might increase the cost of tunnelling. Further, it is observed that not all the GCC members have a similar idea regarding the railway line. Oman and Qatar agree upon an electrified high-speed railway line, but the other four members demand dieselpowered trains all along the line. This would lead to problems where locomotives would need to be changed at borders. Most of the states are in favour of double stacking of the containers for freight transport, for which the electrification may not be possible, as it requires a very high clearance. Qatar, on the other hand, has a clear aim in establishing a high-speed electrified passenger rail as it is hosting the 2022 FIFA World Cup. They can satisfy the requirement of the electrified rail system as they have abundant gas reserves.

Oman has plans to improve the infrastructure linked with the GCC rail as well as extend the development towards Salalah and Duqm ports and further to Yemen. There is another reason why Oman is not opting for the diesel-powered train as its oil reserves are reducing very fast. They have few decent natural gas reserves, which might help in the electrification of the railway lines.

\subsection{Oman railway network}

Oman's vision, with $309,500 \mathrm{~km}^{2}$ area and population of 4.155 million, is the implementation and development of the rail transportation industry to be a vital source of the Omani economy [7]. The objectives of this railway are linking the ports of Oman with the GCC countries network, building a network of highly competitive trading and communication, building a safe and efficient network and an extensive promotional strategy to invest. The expected traffic of freight railway project in Oman refers to the large increase in the Sultanate's economic activity and in the GCC countries. This high rate of volume of cargo comes from the ports of the Sultanate of Oman such as Duqum, Khasab, Salalah and Sultan Qaboos to the GCC line [8].

The Omani government is planning to establish a rail network of a total span of 2,135 km that starts from Sohar (north) to Salalah (south) as shown in Fig. 2. 


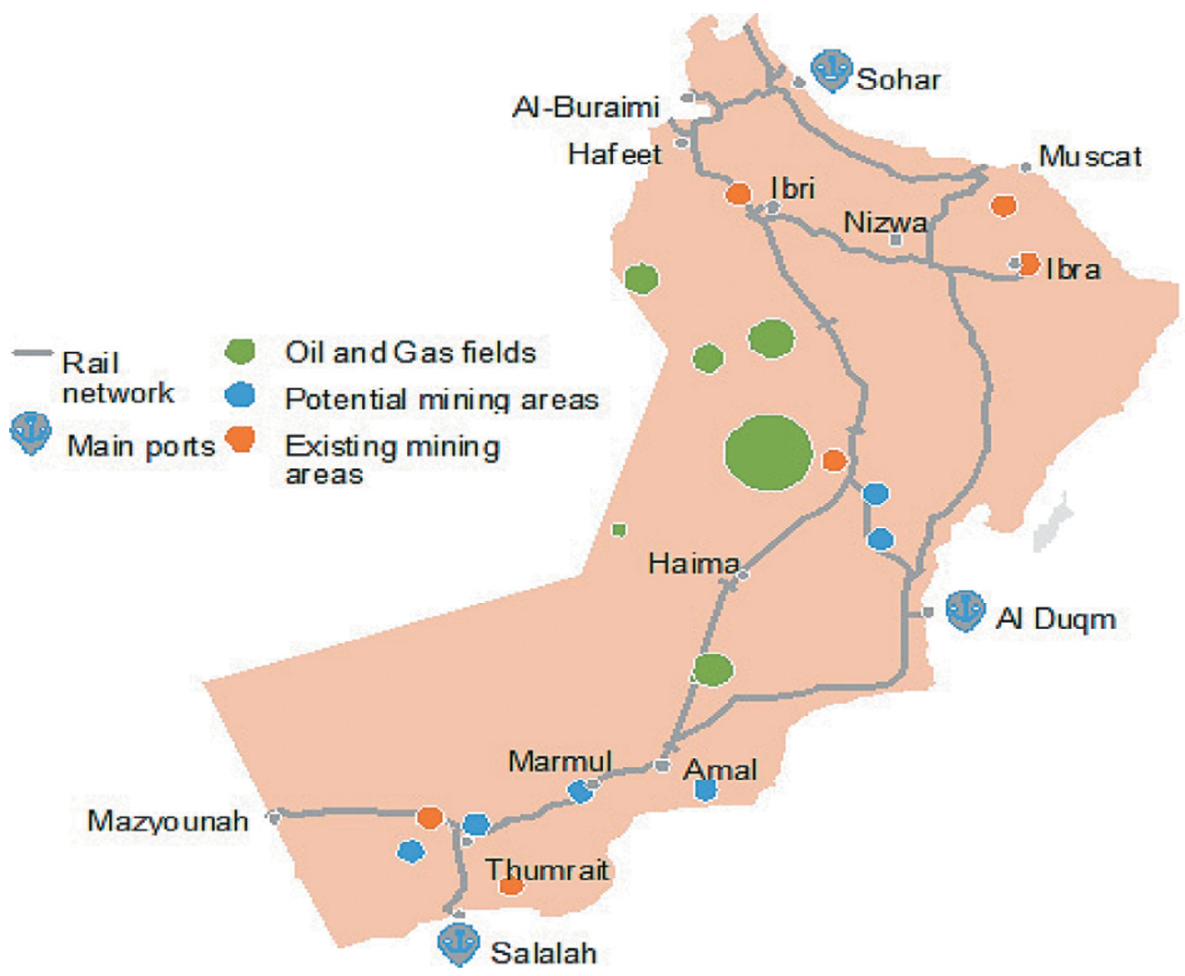

Figure 2: Intercity railways network in Oman [7].

The domestic intercity rail network is intended to link Oman's important ports, mineral deposits, industrial regions and populated areas, among each other and with the boader of the GCC region. The railway network in Oman will also be a part of the main line of the GCC network estimated to be $306 \mathrm{~km}$. This is going to open new opportunities for the mineral resources of Oman, which would in turn stimulate the long-term development of Oman as well as the GCC and Middle Eastern countries.

The work plan for the completion of the railway project in Oman started in 2010 and is finishing in 2018 [7]. In Table 2, according to the meeting, which was held by the authors with Oman Rail Company, based on preliminary design the technical aspects of rail track are summarized.

\subsection{The Kingdom of Saudi Arabia railway network}

The KSA has a significant economic growth among the GCC countries. The area of the KSA is $2,150,000 \mathrm{~km}^{2}$ and the total population is 28.7 million. The first railway service was built 40 years ago in the KSA and few years back the government decided to expand the network domestically and outside. Saudi Arabia is aiming towards the transportation of heavy goods and passengers over long distances. It has few railway lines, which are powered by diesel, and they intend to further develop their GCC line using the same fuel. Saudi Arabia is planning to establish a total length of more than $6,000 \mathrm{~km}$ with a total investment of $\$ 44.8$ billion [1]. This includes the railway line as well as the metro line for major cities like Mecca, Madina, Jeddah, Riyadh, etc. 
Table 2: technical parameters of Oman railway network.

\begin{tabular}{|c|c|c|c|}
\hline Track line & Double & $\begin{array}{l}\text { Shared track } \\
\text { (rail car, traction system ) }\end{array}$ & Double stack, diesel \\
\hline Total length & $2,135 \mathrm{~km}$ & Estimated construction cost & US $\$ 15.5$ billion \\
\hline Axial load & 32.4 tons & Security fencing & $6,500 \& 1,000$ \\
\hline Tunnels & $35 \mathrm{~km}$ & $\begin{array}{l}\text { Heavy duty maintenance } \\
\text { workshops }\end{array}$ & 3 \\
\hline Viaducts & $45 \mathrm{~km}$ & $\begin{array}{l}\text { Central workshop for } \\
\text { maintenance }\end{array}$ & 6 \\
\hline Rail bridge & $39 \mathrm{~km}$ & Track gauge & 1,435 \\
\hline Small stations & 30 & $\begin{array}{l}\text { Radius of the curve vertical } \\
\text { (minimum) }\end{array}$ & $15,000 \mathrm{~m}$ \\
\hline large stations & 6 & Gradient (maximum) & $1.5 \%$ \\
\hline Intermodal yards & 9 & Minimum speed passenger & $220 \mathrm{~km} / \mathrm{h}$ \\
\hline Marshalling yards & 8 & Maximum. speed freight & $120 \mathrm{~km} / \mathrm{h}$ \\
\hline Signalling system & \multicolumn{3}{|c|}{ ETCS level 2 and telecommunication system based on GSM-R } \\
\hline
\end{tabular}

It is the first country that used railways among the GCC countries and it has an experience of constructing and operating heavy railways [9].

In terms of overall expenditure on rail in the Saudi Arabia land bridge project provides access to the Red Sea for the GCC member states by connecting with the GCC railway network [9]. In addition, this land bridge line project will have the maximum annual traffic in the KSA.

\subsubsection{The KSA intercity railway network}

There are five main intercity lines in the KSA such as north-south project, the JubailDammam link, the Saudi Arabia-Bahrain causeway, Haramain high-speed rail and land bridge line as shown in Fig. 3. The total length of the north-south railway project is about $2,800 \mathrm{~km}$ with a total investment of about $\$ 5.3$ billion; $460 \mathrm{~km}$ of the line is shared with mineral traffic operations. The completion of Jubail-Dammam line is estimated to be in 2016. Haramain high-speed rail project is considered to be the first high-speed railway line in the entire region with $360 \mathrm{kph}$ electric trains from Mecca to Medina via Jeddah. This line is primarily intended to transport Hajj pilgrims. The total length is around $445 \mathrm{~km}$ of which $372 \mathrm{~km}$ lies in the Madinah-Jeddah section and $72 \mathrm{~km}$ in the Mecca-Jeddah section [10]. The KSA-Bahrain causeway rail line is expected to run parallel to the King Fahd Causeway that links Manama and Alkhobar. In 2014, both states named the King Hamad causeway. Table 3 shows the number of railway projects proposed for the Saudi Arabian region. Table 4 shows the technical properties of the KSA intercity railway network.

\subsubsection{Urban tracks in the KSA}

There are five ongoing metro projects in the KSA: Jeddah Metro, Dammam, Riyadh, Makkah and Madinah Metro. Some characteristics of these urban lines are displayed briefly in Table 5 . 


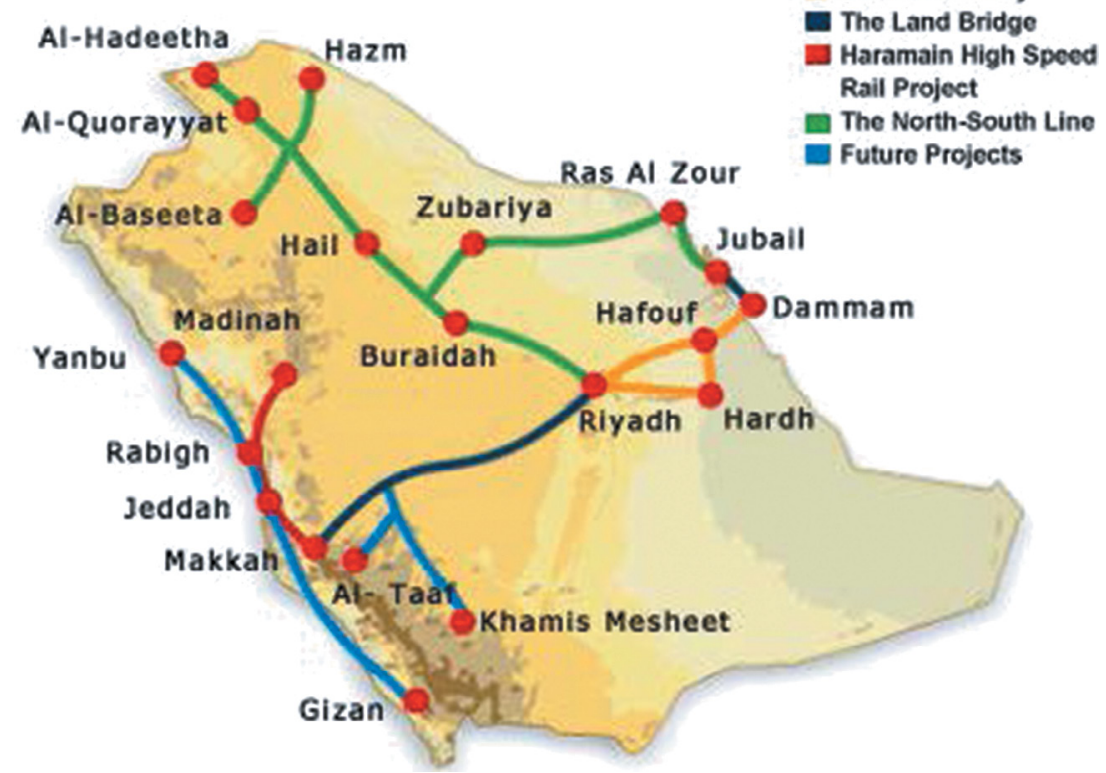

Figure 3: Intercity railway network in the KSA [6].

Table 3: Ongoing projects in the KSA railway network.

\begin{tabular}{lccc}
\hline Project & Length $(\mathrm{km})$ & Proponent & Cost (bn) \\
\hline North-south & 2,800 & SAR & $\$ 5.3$ \\
Jubail-Dammam railway link & 115 & SAR & NA \\
Haramain high-speed railway & 450 & SRO & $\$ 16$ \\
The Saudi Arabia-Bahrain railway & 90 & SRO & $\$ 4.2$ \\
Land bridge & 950 & SAR & $\$ 7$ \\
GCC (Saudi side only) & 400 & SRO & US\$140 \\
\hline
\end{tabular}

Table 4: The KSA intercity railway network - Technical properties.

\begin{tabular}{|c|c|c|c|}
\hline Total cost & $\$ 44.8$ (bn) & Types of sleepers & $\begin{array}{l}\text { Wooden and } \\
\text { concrete }(\mathrm{km} / \mathrm{h})\end{array}$ \\
\hline Maximums axle loads & 32.4 tons & $\begin{array}{l}\text { Maximum design } \\
\text { speed of passenger }\end{array}$ & 200 \\
\hline Maximums dynamic load & 47.9 tons & $\begin{array}{l}\text { Maximum design } \\
\text { of freight trains }\end{array}$ & $100-120$ \\
\hline Maximums gradients trains & $1.5 \%$ & $\begin{array}{l}\text { Maximum train speed } \\
\text { of mineral loaded }\end{array}$ & 80 \\
\hline Train control system & ETCS level 2 & $\begin{array}{l}\text { Maximum design speed } \\
\text { of passenger }\end{array}$ & 200 \\
\hline Utmost trains configuration & & $\begin{array}{l}3 \text { locomotives with } \\
120 \text { wagons }\end{array}$ & \\
\hline
\end{tabular}


Table 5: The KSA urban railway network - Technical properties.

\begin{tabular}{lcccccc}
\hline Project & Length $(\mathrm{km})$ & Proponent & Costs $(\mathrm{bn})$ & Line \# & Station \# & Completion \\
\hline Riyadh metro & 176 & ADA & $\$ 8$ & 6 & 132 & N/A \\
Makkah metro & 114 & MMRTC & $\$ 6.2$ & 4 & 88 & N/A \\
Medina metro & 61 & N/A & N/A & 3 & N/A & 2020 \\
Jeddah metro & 108 & JDURC & $\$ 9.4$ & 3 & 46 & 2020 \\
Dammam metro & 86 & EP & $\$ 16$ & 2 & 54 & 2021 \\
& \multicolumn{7}{c}{ municipality } \\
\hline
\end{tabular}

\subsection{Qatar railway network}

Qatar with 11,437 $\mathrm{km}^{2}$ area and 2.2 million population is hosting the 2022 FIFA World Cup. Investments in the rail transportation systems are one of the key priorities for Qatar at present. Qatar develops a state-of-the-art railway infrastructure and rail operations as a key element of transport planning and an enabler of economic growth [11].

\subsubsection{Intercity railway network in Qatar}

The railway network in Qatar will also be a part of the GCC railway network. Another new project in Qatar is Friendship Bridge as part of the GCC railway network. This 40-kilometre causeway linking Qatar to Bahrain is with four road lanes and two rail lines. The project value is estimated about $\$ 3$ billion [12].

The total length between Qatar and the GCC railways is $283 \mathrm{~km}$. This train runs on electricity (AC, $25 \mathrm{kV} / 50 \mathrm{~Hz}, \mathrm{O} / \mathrm{H}$ catenary). For freight line and passenger line the maximum axle load is 25 tons.

\subsubsection{Urban tracks in Qatar}

The Doha metro system includes four metro lines linking the suburbs with the Doha city centre and the main commercial areas. This will further reduce the congestion. The metro system was intended to be built in two different phases. The four lines include the blue line, red line, golden line and green line. Phase 1 is targeted to be finished in the year 2019 and the second phase in the year 2026. The axle load of these metro lines is 16 tons [12] (Table 6).

\subsection{The Kingdom of Bahrain railway network}

Bahrain has a plan to achieve sustainability in transport infrastructure development and to realize the aspirations of the national economic strategy. Bahrain has integrated transport strategy (ITS) which is a comprehensive public transport network comprising six transit lines with four types of transit technologies (light rail transit (LRT), tramway, bus rapid transit (BRT)/monorail) [13]. The area of this small country is $780 \mathrm{~km}^{2}$ and the total population is 2.2 million.

Table 6: Doha metro line specification.

\begin{tabular}{llll}
\hline Total length of Doha metro & $234 \mathrm{~km}$ & Proposed cost of Doha metro & $\$ 15.2(\mathrm{bn})$ \\
Number of lines & 4 & Number of stations & 96 \\
\hline
\end{tabular}


It is planning rail transit that includes traffic modelling for transit lines, multimodal/urban, integration preliminary detailed engineering design and project management for the delivery of the urban transit (LRT, tramway, BRT /monorail) and regional railway (heavy passenger and goods).

\subsubsection{Intercity railway network in Bahrain}

The Kingdom of Bahrain has the initiative to plan and implement regional rail with the GCC line and Middle East. Also, it will have rail connectivity to both Saudi Arabia and Qatar. The railway passes through the airport, port and the industrial areas of the Kingdom and this rail is for both passenger and freight movements [8]. The total length of the intercity railway network is $87 \mathrm{~km}$; it links the King Hamad causeway of length $26 \mathrm{~km}$ and then the other bridge of $10 \mathrm{~km}$. North of Bahrain will be connected to Saudi Arabia by a new King Hamad causeway constructed parallel to reduce the traffic on the current King Fahd vehicle causeway. In addition, Bahrain has 40-kilometre Friendship Bridge with Qatar on the other side [13]. Bahrain will be connected to Saudi Arabia by new constructing parallel to the existing King Fahd causeway.

\subsubsection{Urban tracks in the Kingdom of Bahrain}

The Kingdom of Bahrain used monorail, LRT, BRT and tramway. The design speed of LRT is $30 \mathrm{~km} / \mathrm{h}$, monorail is between 30 and $60 \mathrm{~km} / \mathrm{h}$ and tramway is $20 \mathrm{~km} / \mathrm{h}$. The total length of the railway network is $184 \mathrm{~km}$. It was started in 2008 and the last phase will be implemented in 2030. The railways have six transit lines with four kinds of transit technologies.

Plans of the implementation of the 184.2-kilometre-long transit line network in Bahrain are defined in three phases. The total capital cost is estimated to be BD 3,060 million. The duration of the first phase is 2009-2016. The total length of tram and LRT network is $24 \mathrm{~km}$. The duration of the second phase is 2016-2021, the total length of transit network is $72.7 \mathrm{~km}$ and the transit technologies are monorail, BRT and LRT [13]. The duration of the third phase is 2022-2030, the total length of transit network is $87 \mathrm{~km}$ and the transit technologies are monorail, BRT, tram and LRT. More details of transit lines in Bahrain are summarized in Table 7.

Table 7: Bahrain urban railway lines specification.

\begin{tabular}{|c|c|c|c|c|c|c|}
\hline Lines & Red & Green & Blue & Orange & Pink & Brown \\
\hline Length (km) & 32.7 & 21 & 29 & 33 & 36.5 & 32 \\
\hline Interchange stations & 8 & 8 & 5 & 2 & 6 & 7 \\
\hline $\begin{array}{l}\text { Commercial speed } \\
(\mathrm{km} / \mathrm{h})\end{array}$ & 40 & 25 & 35 & 25 & 25 & 40 \\
\hline Stations & 18 & 23 & 23 & 26 & 33 & 17 \\
\hline Passengers/hr & 6,000 & 9,000 & 4,500 & 4,000 & 2,500 & 5,000 \\
\hline $\begin{array}{l}\text { Minimum station } \\
\text { spacing }\end{array}$ & $1.9 \mathrm{~km}$ & $950 \mathrm{~m}$ & $1.3 \mathrm{~km}$ & $1.3 \mathrm{~km}$ & $1.1 \mathrm{~km}$ & $2 \mathrm{~km}$ \\
\hline Cities of red line & \multicolumn{6}{|c|}{$\begin{array}{l}\text { Bahrain airport to the Bahrain-Qatar causeway via } \\
\text { the city of Manama }\end{array}$} \\
\hline Cities of green line & \multicolumn{6}{|c|}{ Jufair then to Manama and further to Seef } \\
\hline Cities of blue line & \multicolumn{6}{|c|}{ Jufair to the northern cities and then to Budaiya } \\
\hline Cities of orange line & \multicolumn{6}{|c|}{ Airport to the Diar Island } \\
\hline Cities of pink line & \multicolumn{6}{|c|}{ Riffa, Hamad town, Sitra, Isa town and south of Manama } \\
\hline Cities of brown line & \multicolumn{6}{|c|}{ Manama \& Bahrain International } \\
\hline
\end{tabular}




\subsection{Kuwait railway network}

The location of Kuwait, its richness in natural resources of oil and gas and the extensive commercial relations with other countries help Kuwait to achieve a significant and rapid development [14]. In spite of 4.1 million population and $17,820 \mathrm{~km}^{2}$ area, the high motorist traffic density has led to frequent and usually fatal accidents in the streets of Kuwait. These motives have forced the government to lead a metro railway system in the state [15]. The total predicted cost of development of a national railway and metro network is over US\$17 billion .

The national railroad network seeks to connect ports with key industrial areas and with the GCC railroad network. The national railway and metro network is for both passenger and freight movements [14]. Kuwait railway network is connecting with the KSA. Therefore, the Kuwait national railway is connected to the GCC rail network for passengers and freight. The total length of north-south railroad in Kuwait is estimated to be around $387 \mathrm{~km}$ with 12 stations along the entire length of the road.

The extension of this phase will be from Umm Qasr in Iraq to the Qasr in the Saudi Arabian borders. The total length of the railroad in the second phase is about $118 \mathrm{~km}$. This railroad will run from the west from Salemy and join the north-south railroad at Al Jahrah junction.

According to the master plan of the project, the total of urban railway network is $160 \mathrm{~km}$, and $60 \mathrm{~km}$ of the railway will be built underground. The project will have four lines, each of which will be tendered as separate project [15].

\subsection{United Arab Emirates railway network}

The UAE is one of the fast-developing countries in the GCC countries. It is a federation which consists of seven emirates which are Dhabi, Umm Al-Quwain, Dubai, Fujairah, Ajman, Sharjah and Ras Al-Khaimah. The population is about 4.6 million and the area of the UAE is $83,000 \mathrm{~km}^{2}$ [1]. In 2006, the Dubai metro light rail system was constructed and nowadays short monorail and LRT lines are being operated. The plan of the UAE is to develop the railway network that covers all the emirates and connects with the GCC rail network (Tables 8 and 9).

Table 8: National railways network in Kuwait.

\begin{tabular}{lcll}
\hline $\begin{array}{l}\text { Total proposed length } \\
\text { of intercity railway }\end{array}$ & $511 \mathrm{~km}$ & Total length of the metro & $160 \mathrm{~km}$ \\
$\begin{array}{l}\text { Maximum design speed } \\
\text { of passenger }\end{array}$ & $200 \mathrm{~km} / \mathrm{h}$, & Metro stations \# & 69 \\
$\begin{array}{l}\text { Maximum design speed } \\
\text { of freight }\end{array}$ & $100-120 \mathrm{~km} / \mathrm{h}$ & Total cost (intercity, urban) & US\$17 (bn) \\
\hline
\end{tabular}

Table 9: Two phases in Kuwait rapid transit system

\begin{tabular}{lccc}
\hline Rapid transit system & Orange line $(\mathrm{km})$ & Blue line $(\mathrm{km})$ & Red line $(\mathrm{km})$ \\
\hline Total length (phase 1) & 25.82 & 20.91 & 18.52 \\
Total length (phase 2) & 57.3 & 16.4 & 22.7 \\
\hline
\end{tabular}




\subsubsection{The UAE intercity railway network}

The railway network in the UAE connects the GCC railway network from both ends of the border: Oman and the KSA. Etihad rail network will stretch 1,200 km through the UAE, from the borders of Saudi Arabia to Oman's borders scheduled to be completed by 2018 .

The UAE railway is going to be built in three stages as given below:

- Stage one: The length is $264 \mathrm{~km}$. This route is to transfer granulated sulphur from Shah and Habshan, which is the source from where it is going to be exported, to Ruwais. One line of the first stage is already completed with testing and commissioning of the assets accomplished. Etihad Rail completed all the safety assurance procedures in order to start operating based on the independent safety assessor. In this stage, one being completed the Federal Transport Authority (FTA) allowed Etihad Rail to start commercial operations in December 2015. Today it is transporting 3 million tons and more of sulphur, which equals 200,000 truck trips.

- Stage two: It is the rest of the Abu Dhabi network with connection to Dubai, which is $628 \mathrm{~km}$. It will also connect Abu Dhabi to the KSA border via Ghweifat and the Omani border via Al Ain. By covering the borders of the country from the west and east, the network will link the essential parts of the UAE such as Khalifa port, Mussaffah and Jabl Ali port in Dubai.

- Stage three: The network will be extended beyond Dubai to Sharja, Fujairah and Ras Al Khaimah in the north part of the country on a 279-kilometre railway. This stage is under studies and the aim of the proposed railway is to finish the Etihad freight service, which will transport aggregates from the factories in the north. In this phase passengers train will also be optimized [5].

\subsubsection{Urban tracks in the UAE}

Two main cities in the UAE, Dubai and Abu Dhabi, have planned to develop urban transportation.

With the demand to develop the public transport system in Abu Dhabi, the Department of Transport had decided to have the metro lines in the Abu Dhabi city. The total planned investment in this project is about $\$ 7$ billion. The aim of this metro system is to link the important commercial areas with Reem Island, Yas Island, Al Maryah Island, Saadiyat Island, Masdar, the Abu Dhabi airport and various other important parts of the city. The total land coverage of this metro line will be about $131 \mathrm{~km} \mathrm{[2].}$

In January 2013, the road and transport authority of Dubai decided to extend the already existing metro system of Dubai. The extensions would be carried out for two red and green metro lines.

The Dubai Tram (already the Al Sufouh Tram) framework was intended to be a vital piece of the Dubai transport system, connecting the Dubai Metro and the Palm Monorail and passing along Jumeirah Beach Road and Al Sufouh Road from Mall of the Emirates towards one side of the Dubai Marina. The road and transport authority of Dubai with a total investment of $\$ 1.8$ billion handles this project. It covers $14.6 \mathrm{~km}$ with 17 stations [1].

\subsection{Conclusions}

The aim of this article is to investigate the existing future plans and policies of GCC countries which are Oman, Saudi Arabia, Qatar, Bahrain, Kuwait and the UAE with regard to the shared line and domestic railway network. It surveys the national urban and intercity rail 
Table 10: Comparison between the railway network of the Gulf Cooperation Council countries.

\begin{tabular}{lcccccc}
\hline Country tech. details & Oman & UAE & KSA & Qatar & Bahrain & Kuwait \\
\hline Proposed intercity network & 2,135 & 1,200 & 2,400 & 450 & 87 & 511 \\
length $(\mathrm{km})$ & & & & & & \\
Train speed passengers km/hr & $180-220$ & $200-220$ & $200-350$ & $200-350$ & $\mathrm{NA}$ & 200 \\
Train speed freight km/hr & 120 & 120 & 110 & 110 & $\mathrm{Na}$ & 120 \\
Metro/LRT km (programmed) & - & 907 & 613 & 400 & 184 & 160 \\
Gauge mm & 1,435 & 1,435 & 1,435 & 1,435 & 1,435 & 1,435 \\
Intercity axial load (ton) & 32.4 & 32.4 & 32.4 & 25 & $\mathrm{NA}$ & $\mathrm{NA}$ \\
Cost (\$bn) & 15.5 & 22.4 & 44.8 & 36.8 & 12 & 17 \\
\hline
\end{tabular}

transportation to appraise the potential of passenger movement and commodities transportation at present and in the future. The key purpose of the GCC is to access unity between its members based on their common objectives and their similar political and culture identities.

Regarding their policies, population and natural terrain, it was observed that each of the GCC countries has different railway network systems and plans. Based on comparative investigation, Table 10 shows different track properties and network length. These ongoing railway projects generate opportunities for international companies and researchers. It shows that there is a big boom and development for the upcoming railway transportation in the GCC countries.

\section{REFERENCES}

[1] Ali, M.A.M., Opportunities for high-speed railways in developing and emerging countries: A case study of Egypt, available at https://depositonce.tu-berlin.de/bitstream/ 11303/3640/1/Dokument_9.pdf, 2012 (accessed 23 November 2015).

[2] Berlin, available at http://vae.ahk.de/fileadmin/ahk_vae/ Startseite_Katar/Rail_Workshop/Qatar_Rail.pdf, 2013 (accessed 18 December 2015).

[3] Lowe, G. \& Saud Altrairi, J., The Gulf Cooperation Council railway, available at http: //www.arcom.ac.uk/-docs/proceedings/ar2013-1147-1157_Lowe_Altrairi.pdf, 2013 (accessed 23 November 2015).

[4] GPCA, Gulf Rail connection: Realizing GCC unity, available at http://www.middleeast. atkearney.com/documents/787838/788101/Railway_English_LOW.pdf/f168733ce396-4d0f-89a6-7a757a5fda23, 2014 (accessed 15 November 2015).

[5] ABB group, Rail power ABB UPS for the world's largest railway construction project, available at https://library.e.abb.com /public/ 26b7f2541beed6dbc1257d5f002f8dc0/ Reference-case-study-Railway-Transportation-PW33-PowerScale.pdf, 2014 (accessed 9 December 2015).

[6] Terrapinn.com, Building iconic railway networks across the Arab world Middle East Rail 2016, available at http://www.terrapinn.com/merail, 2016 (accessed 24 November 2015).

[7] Ministry of Transport and Communication, The Railways in Oman, available at http: //gulf.argaam.com/article/articledetail/247015, 2012 (accessed 25 December 2015).

[8] Saeed, S., Economic Development Conference of railways and roads, available at www. chamberoman.com/.../The\%20role\%20of\%20cu, 2013 (accessed 25 December 2015). 
[9] Al Yousfe, H., available at http://www.Saudi\%20 Railway.pdf.com, 2006 (accessed 25 December 2015).

[10] Railway Technology, Haramain High-Speed Rail Project, available at http://www. railway-technology.com/projects/haramain-high-speed/, 2012 (accessed 10 December 2015).

[11] Writer, S., 2015. Bahrain said to spend $\$ 10$ billion on rail, second causeway links, available at http://www.arabianbusiness.com/bahrain-said-spend-10bn-on-rail-secondcauseway-links-591204.html, 2015 (accessed 25 December 2015).

[12] MEED, 2014. Middle East Rail and Metro Projects Report 2014, available at http:// www.meed.com/Journals/2014/04/03/h/w/q/Sample-Content-2014.pdf, 2014 (accessed 10 December 2015)

[13] John, G, The Gulf Cooperation Council Railway, available at http://www.arcom.ac/. uk/-docs/proceedings/ar2013-1147-1157_Lowe_Altrairi.pdf, 2013 (accessed 1 January 2016).

[14] Al-Awadhi, K.A., Kuwait Railroad \& Rapid Transit Systems, available at www. iktissadevents.com/files/events/gtrc/1/.../d1-s3-khaled-al-awadhi.pd, 2011 (accessed 15 December 2015).

[15] Al Sabah, M., Investing in Kuwait, Available at: http://www .kfib.com.kw/images/ kuwait-dipa/investment-guide-en.pdf, 2011 (accessed 27 December 2015). 